\title{
Gender diverse boards and goodwill changes: association between accounting conservatism, gender and governance
}

\author{
Hannu Schadewitz ${ }^{1}$ D . Jonas Spohr ${ }^{2}$
}

Accepted: 31 October 2021 / Published online: 9 November 2021

(C) The Author(s) 2021

\begin{abstract}
We study the relation between board gender diversity and goodwill (GW). GW on the balance sheet is connected to both the firm's risk-taking and its accounting conservatism which are two popular topics in how gender diversity affects the governance of firms. GW captures the firm's decision to acquire another business for a price exceeding the received identifiable net assets and the subsequent valuation of the purchase. We propose that board decisions affecting GW could depict information about board gender diversity and its potential effects. Specifically, we examine Nordic listed firms in the period 2009-2018, to determine whether and how female representation on the board of directors is linked to the GW change. Big GW increases are associated with risk-taking and GW write-downs are signs of conservative accounting. Thus, we hypothesize and evidence that firms with substantial GW increases (decreases) are associated with fewer (more) women on the board. These results provide insight on board composition and potentially also on good governance and their consequences for strategic decision-making. Our findings contribute to the board diversity literature in accounting and corporate governance.
\end{abstract}

Keywords Board composition · Gender · Goodwill impairment · Nordic countries

\section{Introduction}

The increasing influence of women in the boardroom is altering the conventions traditions in firms and their governance. Firms and several countries have issued guidelines or rules to increase the role of women in corporations and on the board

Hannu Schadewitz

hannu.schadewitz@utu.fi

Jonas Spohr

jonas.spohr@abo.fi

1 Turku School of Economics, University of Turku, 20014 Turku, Finland

2 Laboratory of Industrial Management, Åbo Akademi University, Tuomiokirkonkatu 3, 20500 Turku, Finland 
of directors. Not surprisingly, the increasing presence of women in firms has gathered much research. This research is often grounded in traits known, or assumed, to be related to gender and these traits are then used to hypothesize on the outcomes of the increasing gender diversity. For example, risk-aversiveness of women has been showed to lead to less risky financial decisions (e.g. Bajtelsmit \& Bernasek, 1996; Davydov et al., 2017; Faccio et al., 2016; Levi et al., 2014). Aggressiveness and overconfidence of men, on the other hand, have been connected to excessive stock trading (Barber \& Odean, 2001) and more aggressive firm-strategies (Adhikari et al., 2019). Women are often suggested to be more ethical than men (Croson \& Gneezy, 2009; van Staveren, 2014) and followingly less likely to mislead outsiders to achieve personal gains. In line with this, women have been shown to engage less in fraudulent activities like insider trading (Betz et al., 1989) and tax evasion (Reese \& McDougal, 2018) compared to men. When it comes to earnings management, several papers suggest that women have a reducing effect on it (García-Sánches et al., 2017; Srinidhi et al., 2011; Sun et al., 2011). This, in turn, causes earnings to be less biased and have better potential to communicate true economic performance.

The difference between the average woman and man, which much of the gender diversity research is built on, somewhat disappears when the gender characteristics are examined among persons in corporate leadership positions. The women advancing to top positions in firms tend to have different traits compared to the average woman in the general population (Adams \& Funk, 2012; Eagly \& Johnson, 1990; Sila et al., 2016). Environment also has a clear effect on the behavior of women (Gneezy et al., 2009). In fact, it seems that the women directors may be even more risk loving than their male board colleagues (Adams \& Funk, 2012). At the CEOlevel, somewhat contrary to the common belief, women also earn in line with their male counterparts (Bugeja et al., 2012) which is a sign that gender is not connected to risk-taking.

Another problem in the sphere of research linking gender diversity to various outcomes in organizations is the endogeneity issue demonstrated clearly by Sila et al. (2016). Their results suggest that it is not the board gender diversity which is related to firm risk but other factors. Previous research has shown, for example, that corporate governance is better in firms with higher gender diversity (Adams \& Ferreira, 2009; Vähämaa, 2017). Assuming that it is the women who are improving corporate governance quality, and this in turn, decreases the risk of the firm, women would be at least indirectly causing the decreasing risk-taking of the firm. The interpretation of results gets more problematic with results suggesting that it is not gender diversity improving corporate governance (alone) but also (the typically) underlying other factors. García Lara et al. (2017), for example, link discrimination to accounting quality and show that in non-discriminating firms gender is not associated to better accounting quality. Zalata et al. (2021) find that only women with financial backgrounds and fewer outside directorships have a decreasing effect on earnings management. Also the studies showing that men are overconfident compared to women may be the result of other underlying factors driving the results (Deaves et al., 2009, 2010).

More research into the issue how gender is connected to earnings management is called for (Zalata et al., 2021). Most previous studies which investigate the 
connection between women and earnings management (e.g. García Lara et al., 2017; Srinidhi et al., 2011; Zalata et al., 2021) use discretionary accruals as an earnings management proxy. Zalata et al. (2019) provide an exception from these studies when using classification shifting as a measure to show that women CEOs, surprisingly, managed earnings more than their male colleagues before the Sarbanes-Oxley Act. To clarify the relation between women and financial reporting practices, more studies deviating from the norm of using discretionary accruals are warranted. The discretionary accruals measure has been shown to be a noisy proxy for earnings management and it has been noted to correlate with many factors, such as firm growth and profitability (Jackson, 2018; McNichols, 2000).

Our research setting contributes to this research stream by providing evidence on the connection between board gender diversity and goodwill (GW) on the balance sheet. GW is a widely studied asset amongst researchers, and is relevant also to e.g. auditors and investors. In the academic literature, GW has, for example, been connected to earnings management (Hassine \& Jilani, 2017; Jordan \& Clark, 2004), and its write-downs have been found to be value relevant and affect share prices (Knauer \& Wöhrmann, 2016; Li et al., 2010). Furthermore, GW impairments have been associated with effective governance mechanisms, that is, managers exercising their accounting discretion to convey private information about firm performance rather than acting opportunistically (AbuGhazaleh et al., 2011).

GW is also directly linked to decisions made by the board of directors. Amongst the most important duties of the board of directors are approving the firm's strategy and major asset purchases (Larcker \& Tayan, 2016). The board members, often with diverse and long business experience, are in a unique position to assess the strategic and organizational fit of a possible acquisition, and may be less affected than the firm's management by possible biases (Bhagat \& Huyett, 2013; for board attributes and shareholder wealth in mergers and acquisitions (M\&A), see Redor, 2016). Responsible for the firm's financial statements, the board also has a role in acknowledging when previous acquisitions did not turn out as planned, and when acquired asset values need to be written down as a result of the mandatory impairment testing carried out by the firm's management (Larcker \& Tayan, 2016).

In impairment testing, the carrying value of GW is compared with the present value of the estimated future cash flows of the cash-generating units to which the GW is assigned. In impairment testing cash-generating units are defined, sales and profitability forecasts are made as well as an accurate discount rate picked for the present value calculations. These estimates made in impairment testing involve a high degree of judgement (Lev, 2019) and can have a material effect on the firm's financial statements. The effects of decisions regarding GW valuation can be illustrated through technology company Eniro's 2016 annual report (p. 23), where the board of directors explains a GW impairment wiping out $78 \%$ of the company's equity as a result of "a downward adjustment of the anticipated revenue and earnings generation that was used as a basis for previous impairment testing as well as an elevated risk assessment. Approximately 50\% of the impairment losses were attributable to a higher risk premium."

Building on previous mixed findings regarding the connection between board diversity in terms of gender and ethical behavior, as well as gender and risk-aversion, 
we anticipate that a gender-diverse board (GDB) is connected to a firm's GW change. The connection between GW and GDB is interesting for two key reasons. First, it provides more evidence on the connection between a higher representation of women on the board and corporate acquisitions. Second, it sheds light on whether GDB is associated with the tendency to write down impaired GW. Factors affecting a firm's intangible assets and their valuation is part of the research stream whose importance has recently been pointed out once again (Lev, 2019).

To our knowledge, this is the first paper to examine how GDB is associated with the change in GW. The study is related to Levi et al. (2014), as we provide further evidence on the connection between GDB and acquisitions. In a situation, where the profiles and characters for male and female board members resembles each others, GDB could indicate and reflect more generally the underlying firm's good governance and how that is associated with GW valuation. We have conducted the research on a sample of 294 big GW changes from 2009 to 2018 from 261 firms. The sample firms are listed on the stock exchanges in the Nordic countries (Denmark, Finland, Iceland, Norway and Sweden). These countries are among the world leaders in female representation on the board of directors, with an average representation of some $36 \%$ compared with, for example, the US at 26\% (Emelianova \& Milhomem, 2019). Our results suggest that firms with big GW-increasing acquisitions are more likely to have a lower number of females on their board, compared to firms making GW write-downs. These results are in line with the previous studies showing that females are more cautious regarding acquisitions (Levi et al., 2014), and less aggressive when it comes to corporate strategies (Adhikari et al., 2019) and financial reporting (Srinidhi et al., 2011). It should be noticed that it is possible that results with GDBs indicate also good overall governance for these firms.

The paper proceeds as follows. In the next section, we present a literature review on research on gender differences in finance and in the governance of companies. We draw on this previous research and end the section with our hypothesis related to GW changes. We present the data and methods in Sect. 3, continue with the empirical results and robustness tests in Sect. 4, and draw our conclusions in Sect. 5.

\section{Literature review and hypothesis development}

\subsection{Literature review}

A recent report (United Nations, 2020) of the state of gender equality worldwide states that women held $28 \%$ of managerial positions in 2019. Although the report concludes that especially in the corporate world the women influence is taking place slowly but with an accelerating rate, such as women's advancement in education and politics, that this will change. Several countries give tailwind for this change by legislation. Among other things, countries (e.g. Belgium, Germany, France, Italy, Norway) and some states in the US (e.g. California, Colorado) have set quotas for women on corporate boards. In the following we will review literature regarding how the gender affects the financial performance, risk-taking and the ethical conduct of firms. While we think that the consensus of this research is that gender makes a 
difference regarding these issues, we show that previous results are mixed. We conclude the literature review by going through some interesting explanations for the results.

Many studies covering various markets report a positive association between women and financial performance: Campbell et al. (2008) use Spanish data; Moreno-Gómez et al. (2018) Colombia data; Kilic and Kuzey (2016) Turkey; Reguera-Alvarado et al. (2017) Spanish; Hodigere and Bilimoria (2015) and Erhardt et al. (2003) use US data; Thiruvadi and Huang (2011) draw from the S\&P Small Cap 600; Siekkinen (2017) from all EU countries, and also from Switzerland, Norway, Iceland, and Liechtenstein; Isidro and Sobral (2015) the largest European firms in the FT 500 Europe; Luckerath-Rovers (2013) Dutch data; and Nielsen and Huse (2010) Norwegian. However, Post and Byron (2015) suggest in their literature review that relation between GDB and financial performance is somewhat mixed in previous studies. Thus, there are studies finding no relation between GDB and financial performance. From a sample of major US firms, for example, Carter et al. (2010) reported that GDB produced no significant relationship between gender and financial performance. Also Rose (2007), using Danish data, and Mateos de Cabo et al. (2011), using Spanish data, found no significant link between GDB and firm performance. One reason given for non-significance of GDB is that if females are clearly in the minority on the board, it could be that they adopt and adapt to the ideas of the majority of board members. Research by Joecks et al. (2013) uses the term "critical mass" to describe the optimal combination of females and males on the board.

Papers suggesting an outright negative connection between GDB and financial performance, seem to measure more what market participants estimate the effect of women to be than the real performance. Using a sample of UK firms covering 2001-2005, Haslam et al. (2010), for example, find that firms with all male boards have a valuation premium. As on explanation for this result, the researchers suggest that investors perceive women appointments to be a sign that the company is in some kind of crisis. Relatedly, Ahern and Dittmar (2012) suggest that after Norway imposed a law requiring at least $40 \%$ of Norwegian firms' directors to be females, the valuations of local firms decreased partly because this led to younger and less experienced boards. These results are in line with a previous study finding women CEO appointments to be associated with negative stock price reactions (Lee \& James, 2007). Contrary results are provided by Campbell and Minguez Vera (2010) who reported that stock markets react positively in the short- and long-term to the announced appointment of female directors.

The research into how a greater share of women on the board of directors affects the firm's risk-taking generally point towards women participation reduces the risk of the firm. Women board members have been found to reduce risk when it comes to investments in R\&D (Chen et al., 2016), and to reduce enthusiasm towards acquisitions (Levi et al., 2014). More specifically, having a woman on the board reduces acquisitions by $7.6 \%$ and the bid premium paid in acquisitions by $15.4 \%$ (Levi et al., 2014). Adhikari et al. (2019) find that firms with female influence on their boards face fewer lawsuits due to avoiding risky firm policies. Contrary to these results, using an Italian sample Rossi et al. (2018) find that the leverage of firms increases 
with women on the board which they explain by women participation reduces agency costs. Hutchinson et al. (2015), using an Australian sample, found that gender diversity on the board reduces firm risk. Also the results of Ingersoll et al. (2019) point towards differences between gender at the CEO-level regarding risk-taking but it is driven by the narcissism; narcistic men CEOs take on more risks compared to narcistic women.

Studying more than 900,000 companies in the UK, Wilson and Altanlar (2011) find that companies with more female directors on the board have a lower insolvency risk. In line with this, Faccio et al. (2016) show that companies with women CEOs adopt less risky policies than those governed by men and are even able to document a reduction of leverage and the variance of ROA when a man CEO is succeeded by a woman. On the other hand, a study using a sample of listed French companies over the period 2006-2010 (116 firms and 478 firm-year observations), found that board gender diversity did not affect firm risk-taking (Bruna et al., 2019). Bruna et al. (2019) suggest that their results are the consequence of boards not being directly in charge of firm administration and management. They used the standard deviation of return on assets as the primary measure of corporate risk-taking. Applying more refined risk measures to S\&P data for the period 1997-2013, Chen et al. (2019) found that GDBs displayed more caution, addressing reputational risks associated with aggressive tax strategies.

When it comes to risk-taking in finance, research suggest that women mitigate the risk-seeking and overconfident behavior of men, and thus likely help improve investment performance (Barber \& Odean, 2001; Davydov et al., 2017; Huang \& Kisgen, 2013). Palvia et al. (2015) discovered that in the context of US commercial banking, female CEOs and chairwomen were more conservative and risk-averse than their male counterparts. On the other hand, when investigating listed banks in midst of the financial crisis, Adams and Ragunathan (2015) did not find that more woman directors would have led to less risk-taking activities in the banks.

Adams and Ferreira (2009) suggest that women improve the monitoring of the firm's management. They find that women have higher attendance on board meetings and are more often a member of the audit committee and corporate governance committee. Women also prepare for board meetings better compared to men. Terjesen et al. (2009) reviews research covering more than 400 publications in a wide variety of subjects. Regarding boards, there is evidence that women on boards enhance governance performance, decision making, on board behavior and culture, independence, and on board skills, knowledge and experience. More recently, Terjesen et al. (2016) reports that gender diversity enhances board of directors' independence and efficiency. In addition, Nielsen and Huse (2010) found that women on boards influenced board processes and, in turn, strengthened board strategic and operational control. Well-functioning board processes are important because diversity could either improve (new perspectives, enriching available information, better processes) or hinder (increased divisiveness, conflicts) effective team performance (Gul et al., 2011, and literature cited therein). In the auditing context, Hardies et al. (2016) report that female auditors are, ceteris paribus, more likely to issue goingconcern opinion than male auditors. Board gender diversity has been connected to the informativeness of stock prices. Gul et al. (2011) show that stock prices of firms 
with gender diverse boards reflect more firm-specific information, i.e. BGD impacts transparency and thereby affect stock price informativeness.

Moving deeper into the evidence regarding possible differences in ethics between the genders, the consensus seems to point towards women being more ethical than men. According to Perrault (2015), real and symbolic representations of women enhance perceptions of the board's instrumental, relational and moral legitimacy. According to the study, these characteristics will strengthen the board's appearance of trustworthiness e.g. for shareholders. In a similar vein, Wahid (2019) discovers that GDBs are related with fewer financial reporting errors and engage in less fraud. Wahid's interpretation of these results is a change in the board's group dynamic. Francis et al. (2014) find that a female CFO and Lanis et al. (2017) find that the proportion of women on the board of directors, are negatively correlated to the companies' tax aggressiveness. A higher share of women on the board of directors has a positive effect of the companies' CSR practices (Bear et al., 2010; Zhang et al., 2013). Furthermore, women are also more open to report CSR related issues, such as climate change disclosures, on voluntary basis (Ben-Amar et al., 2017).

Contrary results regarding women and ethics are provided by Zalata et al. (2019) who found that female CEOs are not more ethically sensitive than their male counterparts. Their results are based on earnings management by classification shifting behavior, i.e. reporting core expenses as special items, by CEOs around the Sarbanes-Oxley (SOX) Act. Specifically, during pre-SOX period, classification shifting was high by both female and male CEOs. Following the punitive SOX Act, classification shifting declined significantly for firms with female CEOs but not for those with male CEOs. Zalata et al. (2019) explain this with the higher risk-aversion of women CEOs. Related to this, previous studies using discretionary accruals are earnings management proxy have found that women reduce earnings management (García-Sánches et al., 2017; Srinidhi et al., 2011; Sun et al., 2011). Somewhat contrary to these results, Zalata et al. (2021) suggest that it is only the women directors with financial expertise and a limited amount of outside board memberships who reduce earnings management. García Lara et al. (2017), in turn, hypothesize that the association between women and less earnings management is only present in discriminating firms as women directors in these firms are especially qualified. In a discriminating environment, women making it to the top must be clearly better alternatives than the men candidates. On the other hand, women representation on the board of directors may not be evidence of a highly qualified (or ethical) board if the appointments are a result of other factors such as belonging to the right family (Mateos de Cabo et al., 2011).

The question what exactly is the underlying cause leading to the observed better financial performance, less risk-taking or seemingly better ethics in some previous studies is an important question. Endogeneity issues are surely at play in many of those studies linking gender to some factor (Sila et al., 2016; Sundén \& Surette, 1998). Maybe due to this, seemingly contradictory results can be found even in the same study as Hutchinson et al. (2015) find that gender diversity boost financial performance but not firm value, which the authors see as an illustration of how complex the study topic is. Another issue possibly explaining the mixed results is the fact that in some settings gender may not be that important explanatory variable at all. 
Organizational culture, for example, may be more important. Croson and Gneezy (2009) note that the population where women and men belong could affect the results of gender studies.

Another issue is that it is likely that people employed as managers and other professional business persons differ from the general population. Thus, assumptions based on the behavior of the average man and woman cannot be extrapolated to the directors and managers at a firm. To be promoted in corporations requires women to adjust themselves to often masculine corporate culture. This, in turn, causes women to break glass ceiling and having different traits compared women in the general population (Adams \& Funk, 2012; Adams \& Ragunathan, 2015; Sila et al., 2016). In fact, there is some evidence that the women directors may be even more risk loving than their male board colleagues (Adams \& Funk, 2012). Gneezy et al. (2009) found that the culture in with women live in affects the competitiveness of women and Bugeja et al. (2012) concluded that at the CEO-level, women earn in line with their male counterparts. Women earning as much as men is taken as a sign that gender does not make any difference at the top.

\subsection{Hypothesis formulation}

In this paper, we analyze the impact of GDB in a GW context. The term GW refers to the difference between the purchase price of an acquired business and the fair value of its identifiable assets (minus identifiable liabilities) (Stolowy et al., 2013). GW represents the value (to the acquirer, at the time of the acquisition) of the intangible elements of a firm's value, such as the customer base, brand, ongoing R\&D projects, and expertise of key personnel (Stolowy et al., 2013).

The International Accounting Standards Board (IASB) sets International Financial Reporting Standards (IFRS), one of which is IAS 36 Impairment of Assets (www.ifrs.org/issued-standards/list-of-standards/ias-36-impairment-of-assets/). The core of IAS 36 is described in the aforementioned link as follows: "The core principle in IAS 36 is that an asset must not be carried in the financial statements at more than the highest amount to be recovered through its use or sale. If the carrying amount exceeds the recoverable amount, the asset is described as impaired. The entity must reduce the carrying amount of the asset to its recoverable amount, and recognize an impairment loss. IAS 36 also applies to groups of assets that do not generate cash flows individually (known as cash-generating units)."

IAS 36 principles should be applied to GW acquired in a business combination. As an intangible asset, GW valuation and its impairment testing comprise a great deal of discretion and related assumptions required in the valuation (AbuGhazaleh et al., 2011; Giner \& Pardo, 2015; Lev, 2019). Furthermore, due to information asymmetry, the accuracy and correctness of these assumptions are hard for outsiders to verify. Because accounting principles allow leeway, also decision makers' ethical and risk-aversion dimensions and experience influence reported accounting outcomes (Smieliauskas et al., 2018; Zalata et al., 2019). GW accounting under IFRS has specific characteristics. Once the original defined value of GW is recorded in the accounts, it cannot later be registered at a higher value. In addition, once performed, 
impairment entry is not reversible. These characteristics potentially effect managers and their caution in defining the original price for GW and its impairments through time.

A well-functioning board supports setting an accurate purchase price of an acquisition and, in turn, the accurate assessment of GW value at the time of execution. How precise and realistic the GW amount and related assumptions in fact are, will then be revealed through yearly post-acquisition impairment testing. GW additions are indications of corporate acquisitions and GW reductions are most likely due to GW write-downs. The board has an important strategic role to play in corporate acquisition and GW valuation, since acquiring a firm is a large, multidimensional project processed and decided upon by the upper echelon. The following articles characterize some of the aspects related to firm acquisition.

Srivastava (2018) analyzed an M\&A case and the steps of the M\&A process, revealing that it is complicated and also emotions have an influence on decisions. Knauer and Wöhrmann (2016) studied the impact (market reaction) of GW impairments. Markets judge GW write-downs as bad news and therefore market reactions are negative to write-down announcements. The magnitude of the negative market reactions is related to a country's level of legal protection, the quality of managers' explanations, and whether the explanation given for the write-down was internal or external. The paper did not analyze GDB. With regard to GW reporting, Glaum et al. (2013) analyzed its compliance for a large sample of European firms mandatorily applying IFRS. Despite the fact that all the studied firms were required to follow IFRS in their reporting, there were significant differences amongst GW reporting and compliance. Again, the paper did not tackle the theme of GDB (Glaum et al., 2013).

Given the importance of GW, we set out to investigate whether GDB is associated with the change in GW. Our study contributes to the numerous previous studies documenting likely developments when the influence of women is increasing in firms. We build on the outlined previous research showing that women are, primarily, more risk-averse, demonstrate more prudence with regard to accounting, combined, usually, with higher ethical standards. Based on this, we conjecture that GW decreases (increases) are more likely in firms where female influence in the board of directors is higher (lower). We believe this connection should be evident in cases where the $\mathrm{GW}$ change is material, because in these cases, the decision has been preceded by a thorough deliberation on the part of the board. Our hypothesis is as follows:

$\mathrm{H}$ : Large GW increases are associated with less GDB than large GW decreases.

Regarding potential connection GDB has on good governance we do not have adequate data to analyze this matter directly. However, we are not excluding this possible connection and will address this matter further in our conclusions.

\section{Data and methods}

To test our hypothesis, we retrieved data from the Orbis database. We started with all Nordic listed firms for the years 2009-2018, other than those in the financial industry. We concentrate on the Nordic markets because they represent a fairly 
homogenous group of countries in terms of national cultures (Gregoric et al., 2017). Karaibrahimoglu and Cangarli (2016) group the Nordic countries together (Nordic cluster) based on the similarities in their cultural values, such as high future orientation, egalitarianism, institutional collectivism, and uncertainty avoidance.

Characteristically, gender equality is important in the Nordic countries. In line with that, there is institutional pressure for gender-balanced boards, one indication of which is the vivid discussion on gender quotas for boards. Compared with many other countries and regions in the world, female board representation (FBR) is nowadays high in the Nordic countries. Brieger et al. (2019) reported that FBR was already, as of 2010, an important factor prior to gender quota legislation. Especially in Finland and Sweden, FBR was over $20 \%$ when the mean in the 30 other surveyed countries was around $8 \%$.

From the retrieved dataset, we calculated the change in GW for 4284 firm-years, which we scale by (beginning) total assets. Many GW changes are very small in absolute terms, so we exclude observations where the GW change is below 10 million euros, leaving a total of 998 firm-years of GW changes. Since we are interested in observations that are the result of thorough deliberations by the board of directors, the focus is on the most material GW changes. Thus, we sorted the data based on the variable GW change through total assets (from largest value to smallest), and focus on the quintiles with the biggest GW increases and GW decreases. For the 199 firm-year observations in the first quintile with the biggest GW decreases, we found the required information for 141 firm-years, and for the fifth quintile with the biggest GW increases we found all the required governance, accounting and market information for 153 firm-years. The information on board members at the end of the annual period for the GW change was collected from the firms' annual reports. The sample formation is displayed in Table 1.

For the observations with large GW changes, we collected the following governance information from the annual reports: CEO gender, number of board members and their gender, and whether the CEO is a board member. From the Orbis database, we collected the following accounting and market data: firm net sales, net income, total assets, shareholder equity, and market capitalization. These data were used to construct variables listed and motivated below, and also summarized in Table 2

Table 1 Formation of the sample with large GW changes

\begin{tabular}{lcc}
\hline Sample formation & Firm-years \\
\hline $\begin{array}{l}\text { Nordic observations for years 2009-2018 } \\
\text { With no GW }\end{array}$ & 5149 \\
With GW value & -865 \\
With GW change less than 10 million euros & -3284 \\
With GW change of 10 million euros or more & 998 \\
Observations in the 1st and 5th quintiles of GW change & 398 \\
Observations with missing data & -104 & 141 \\
Final GW decrease sample (1st quintile) & & 153 \\
Final GW increase sample (5th quintile) & & \\
\hline
\end{tabular}


Table 2 Variables and their definitions

\begin{tabular}{|c|c|c|}
\hline Variable & Description & Calculation \\
\hline $\mathrm{GW} \Delta \mathrm{D}$ & GW-change dummy & $\mathrm{GW}$ decreases $=1, \mathrm{GW}$ increases $=0$ \\
\hline FBOD & Number of women on board of directors & Only ordinary members accounted for \\
\hline F\%BOD & Share of women on board of directors & Females as $\%$ of total board size \\
\hline FCEOD & Female CEO dummy & Female $\mathrm{CEO}=1$, male $\mathrm{CEO}=0$ \\
\hline WeakCGD & Weak corporate governance dummy & $\begin{array}{l}\text { CEO is member of board of directors }=1 \text {, } \\
\text { otherwise }=0\end{array}$ \\
\hline SALES & Net sales & Natural logarithm of EUR ' $000 \mathrm{~s}$ \\
\hline ROA & Return on total assets & $\begin{array}{l}\text { Net income divided by total assets beginning at } \\
\text { execution of acquisition }\end{array}$ \\
\hline EQUITY\% & Solvency ratio & Shareholders' equity divided by total assets \\
\hline $\mathrm{B} / \mathrm{M}$ & Book-to-market ratio & $\begin{array}{l}\text { Shareholders' equity divided by market capi- } \\
\text { talization }\end{array}$ \\
\hline
\end{tabular}

below. The financial data were used to control for the possible endogeneity bias in our analysis. Certain firm characteristics may be connected to GW change and, if these characteristics are also connected to gender, we take a risk for incorrect interpretations if we do not control for these firm characteristics.

Firm size may be positively connected to GW write-downs (Godfrey \& Koh, 2009), and also to degree of female representation on the board of directors. We control for firm size through net sales (natural logarithm), which is not a forwardlooking size proxy (Dang et al., 2018) and has a relatively low correlation with our other independent variables. Previous research has shown that low or decreasing ROA is connected to GW write-downs (Chalmers et al., 2011; Francis et al., 1996), as weak profitability makes it difficult to justify the value of GW on the balance sheet. In addition, high leverage may make the firm less willing to write down GW because it could lead to increased costs (Chalmers et al., 2011; Godfrey \& Koh, 2009). We control for the potential effect of solvency with EQUITY\%. Our next control variable is book-to-market $(\mathrm{B} / \mathrm{M})$. A high $\mathrm{B} / \mathrm{M}$ multiple indicates that the market forecasts either meager returns on equity or estimates the firm's assets to be overvalued. This relation between the book and market values has been linked to GW write-downs in previous research (Giner \& Pardo, 2015).

Verriest and Gaeremynck (2009) used board independence to show that weak corporate governance is connected to an unwillingness to make GW write-downs. We control for board independence by including a variable (WeakCGD) controlling for whether the CEO is also a member of the board of directors. Our interpretation is that when the CEO is also a member of the board it generally weakens the board. In addition to these control variables, we use period controls and industry controls in our analysis.

We further gathered information for one year before (year - 1) the large GW change year (year 0), which increased our number of observations in the regressions using two years to a total of 606 (294 in year $0 ; 312$ in year - 1). We include the year preceding the event year because we stipulate that the strategy to grow through 
acquisitions, find a suitable acquisition candidate, and complete the acquisition, is probably a process taking more than one year. Similarly, recognizing GW impairments may also have a gestation period before they are finally realized. Our main variables used in the analysis are listed and defined in Table 2.

Table 3 shows the Pearson correlations for our main regression variables. The number of female directors on the board (FBOD) and the relative share of female directors on the board (F\%BOD) show a high positive correlation. These variables have low but positive correlations to the GW-change dummy variable (GW $\Delta \mathrm{D}$ ) which is valued as 1 for GW decreases. We use a dummy variable measuring the GW change because we do not expect there to be a linear relationship between our independent variables of interest and the GW change, especially as several of the GW changes are of very high magnitudes (even larger then assets at the time of execution). Also, previous research has applied dummy variables to account for changes in GW (e.g., Francis et al., 1996; Giner \& Pardo, 2015). GW decreases are negatively connected to our variable of weak corporate governance (GW increases are related to weaker boards), and positively connected to sales (GW decreases are related to larger net sales). Larger companies as measured by sales also appear to have more women (in absolute and relative terms) on their board of directors (FBOD and F\%BOD, respectively). We also ran non-parametric (Spearman) correlations for the variables, and the results are comparable to the above, with the exception that ROA $\left(r_{s}=-0.195\right)$ and $B / M\left(r_{s}=0.143\right)$ are now statistically significantly correlated to $G W \Delta D$. Due to the high correlation between the variables measuring female board membership, we use these variables in separate regressions to decrease multicollinearity issues in our analysis.

Women may more likely be found on the board of directors in certain types of company. Based on the correlation analysis, board membership of females is higher in larger companies. To control for this endogeneity problem, we investigate our research question, whether females are connected to GW change, using a regression with several control variables. We use a logistic regression where the dependent variable is 1 for $\mathrm{GW}$ decreases and 0 for $\mathrm{GW}$ increases, to check for whether female representation makes a difference. Due to our sample selection process, we already

Table 3 Pearson correlation for the variables in year 0

\begin{tabular}{lcccccccc}
\hline & GW $\Delta$ D & FBOD & F\%BOD & FCEOD & WEAKCGD & SALES & ROA & EQUITY\% \\
\hline FBOD & $0.169^{* *}$ & & & & & & & \\
F\%BOD & $0.117^{* *}$ & $0.859^{* *}$ & & & & & & \\
FCEOD & -0.004 & -0.042 & -0.035 & & & & & \\
WeakCGD & $-0.099^{* *}$ & -0.014 & $-0.112^{* *}$ & -0.063 & & & & \\
SALES & $0.184^{* *}$ & $0.434^{* *}$ & $0.023^{* *}$ & -0.004 & $0.085^{*}$ & & & \\
ROA & -0.037 & 0.064 & 0.077 & 0.007 & 0.022 & $0.022^{* *}$ & & \\
EQUITY\% & -0.057 & $-0.980^{* *}$ & -0.037 & $0.084^{*}$ & -0.015 & $-0.298^{* *}$ & $-0.106^{* *}$ & \\
B/M & 0.007 & 0.042 & 0.029 & -0.014 & -0.022 & -0.057 & -0.016 & $0.267^{* *}$ \\
\hline
\end{tabular}

The definition of each variable is shown in Table 2. Statistical significance (two-tailed) on the 0.05 and 0.01 levels is reported by ** and *, respectively. The number of observations (n) is 294 (141 GW decreases and $153 \mathrm{GW}$ increases) 
know that both subsamples have substantial changes in GW, but their magnitude is probably not directly related to the degree of gender diversity. Our regression is as follows:

$$
\begin{aligned}
\mathrm{GW} \Delta \mathrm{D}= & \mathrm{a}_{0}+\mathrm{a}_{1} \mathrm{FBOD}(\text { or F\%BOD })+\mathrm{a}_{2} \text { FCEOD } \\
& +\mathrm{a}_{3} \text { WeakCGD }+\mathrm{a}_{4} \text { SALES }+\mathrm{a}_{5} \text { ROA } \\
& +\mathrm{a}_{6} \text { EQUITY } \%+\mathrm{a}_{7} \mathrm{~B} / \mathrm{M} \\
& +\mathrm{a}_{8} \text { Industrycontrols }+\mathrm{a}_{9} \text { Periodcontrols }+\varepsilon,
\end{aligned}
$$

where,

FBOD is the number of women on the board of directors. In the alternative regression, this variable is replaced by $\mathrm{F} \% \mathrm{BOD}$, which is the percentage of females on the board of directors. The variable FCEOD is a dummy variable valued 1 if the firm has a female CEO. WeakCGD is a dummy variable valued 1 if the CEO is also a board member. It is noteworthy that F\%BOD and WeakCGD are significantly negatively correlated. This correlation support the view that low GDBs exist with weakly governed firms. SALES is the natural logarithm of sales. ROA is the net income through total assets. EQUITY\% is the total equity through total assets, and $\mathrm{B} / \mathrm{M}$ is the book-to-market multiple (specific definitions in Table 2).

We include industry controls for the major (two-digit GICS) sectors in our sample (industrial, consumer discretionary, health care, information technology), and classify the other industries as "group other". Group other includes observations from five industries and $21 \%$ of our observations. Female representation on the board of directors has probably increased through our sample period. The results would be biased, if more acquisitions was more common at the beginning of the sample period and, in turn, more GW decreases at the end of the sample period. Thus, we include a period dummy controlling for whether the GW change occurred in the first five years or last five years of our sample period, i.e. periods 2009-2013 and 2014-2018. From the graph in Emelianova and Milhomem (2019, p. 20), there is a clear tipping point upwards for female representation on the board of directors, around year 2014. In our data, the average female representation on the board of directors was over 15\% higher in the period 2014-2018 compared with 2009-2013.

\section{Results}

\subsection{Descriptive statistics}

The descriptive statistics for the GW increase and GW decrease samples are shown in Table 4. More of the GW decrease sample firms have a female CEO compared with the GW increase sample, but, on the whole, women CEOs are rare (5\% of total sample in year 0). The GW decrease sample has on average 0.5 female board member more compared with the GW increase sample, and there is also some indication that its relative number of women (F\%BOD) is somewhat higher. In the GW increase sample, more often the CEO sits on the board of directors (our variable WeakCGD) compared with the GW decrease sample, which may be a sign that the 
Table 4 Descriptive statistics for the two samples for year 0 (big GW change year)

\begin{tabular}{|c|c|c|c|c|c|c|c|c|}
\hline & \multicolumn{3}{|c|}{ GW increase sample $(n=153)$} & \multicolumn{3}{|c|}{ GW decrease sample $(n=141)$} & \multicolumn{2}{|c|}{$\begin{array}{l}\text { Test of difference } \\
\text { (p-values) }\end{array}$} \\
\hline & Mean & Median & SE & Mean & Median & SE & Means & Medians \\
\hline $\mathrm{GW} \Delta \mathrm{D}$ & 0.830 & 0.248 & 13.755 & -0.086 & -0.053 & 0.099 & 0.122 & 0.000 \\
\hline FBOD & 1.915 & 2.000 & 1.154 & 2.460 & 2.000 & 1.322 & 0.000 & 0.000 \\
\hline FCEOD & 0.022 & 0.000 & 0.148 & 0.062 & 0.000 & 0.241 & 0.065 & 0.065 \\
\hline F\%BOD & 0.259 & 0.250 & 0.134 & 0.296 & 0.300 & 0.129 & 0.009 & 0.012 \\
\hline WeakCGD & 0.249 & 0.000 & 0.432 & 0.153 & 0.000 & 0.360 & 0.024 & 0.024 \\
\hline SALES & 12.593 & 12.456 & 1.492 & 13.467 & 13.454 & 1.797 & 0.000 & 0.000 \\
\hline ROA & 0.042 & 0.050 & 0.156 & -1.791 & 0.006 & 24.933 & 0.305 & 0.000 \\
\hline EQUITY\% & 0.421 & 0.402 & 0.144 & 0.399 & 0.399 & 0.230 & 0.260 & 0.376 \\
\hline $\mathrm{B} / \mathrm{M}$ & 0.805 & 0.440 & 2.156 & 0.479 & 0.508 & 5.772 & 0.509 & 0.046 \\
\hline
\end{tabular}

Year 0 is the year of the big GW change. The p-values (two-tailed) are from tests of difference in means (t-test) and medians (Mann-Whitney U) for the two samples. The definition of each variable is shown in Table 2

first-mentioned firms are more often entrepreneur-led growth firms. In addition, the figures for WeakCGD could represent weaker corporate governance in GW increase sample firms. WeakCGD variable indicates better corporate governance for GW decrease sample than for GW increase sample. Furthermore, the GW decrease sample firms seem to be bigger (mean SALES higher, difference in means significant). ROA (median) indicates lower profitability for the GW decrease firms compared with the increase sample. In both samples, the ROA figure is affected by a few observations with very low total assets compared to their (negative) net income number. It should be mentioned that with EQUITY\% values and B/M values there were no statistically significant differences between GW increase and GW decrease sample.

The industry-distribution in the two samples is similar (not reported). The three biggest industries in the GW increase sample are industrials (38\%), information technology (17\%), and consumer discretionary $(16 \%)$; in the GW decrease sample they are industrials (35\%), consumer discretionary (18\%), and information technology (15\%).

\subsection{Regression results}

The results of our regressions, run on two panels of data, are shown in Table 5. First, we focused on the year of the large GW change (year 0), and then included also data from the year before (year -1 ) to explain the dependent variable. We use two years to secure that we capture the influence of women. Board members may not have sufficient knowledge or influence to act in the first year of their membership. For both time periods, we ran two regressions which differed only in regard to the variable of interest (FBOD or F\%BOD). 
Table 5 Logistic regression results

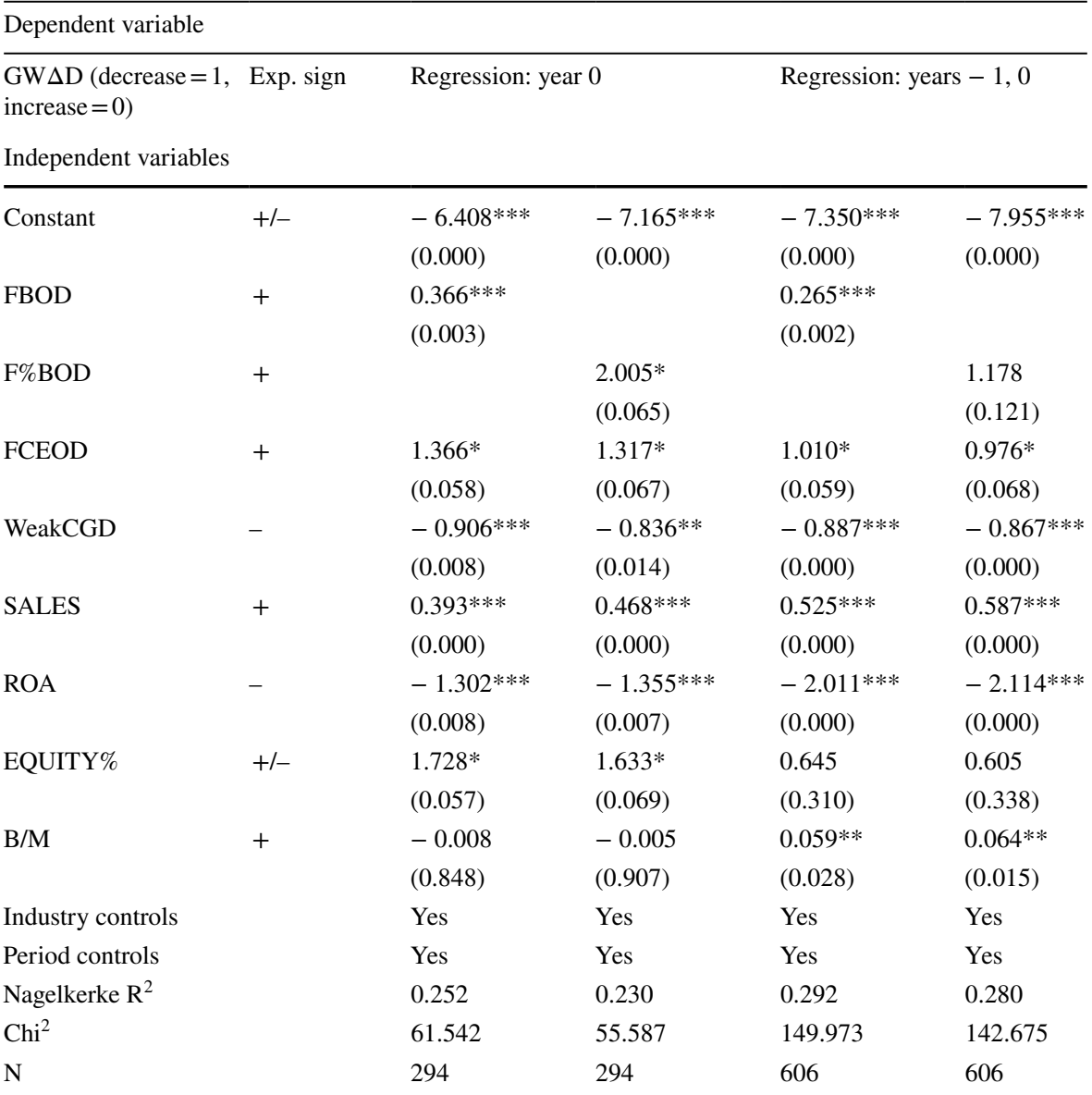

Year 0 is the year of the big GW change, and year -1 is the preceding year. The p-values are reported in parentheses (two-tailed), and the significance levels of the coefficients are indicated with $*$, ** and $* * *$ for the significance levels of 0.1, 0.05 and 0.01, respectively. Industry controls are based on two-digit GICS classification, and period controls are dummy variables differing between observations for years 2009-2013 and 2014-2018. The other variables are defined in Table 2

The results show that our control variables are mostly significantly connected to the GW $\Delta \mathrm{D}$ in the way we expected. All regressions show that the CEO's membership of the board of directors (WeakCGD) appears to make GW decreases less likely and GW increases more likely. This is in line with Verriest and Gaeremyncks' (2009) finding that weak corporate governance reduces the occurrence of GW writedowns. Investigating our sample, typical firms where the CEO also sits on the board are those where the CEO is the founder and/or a large shareholder. Size (measured by SALES) is positively connected to GW decreases which has been documented also in previous studies (Francis et al., 1996). Mature and bigger firms are more likely to have grown through acquisitions, and therefore also face a bigger risk of 
having impaired GW on their balance sheet. As expected, profitability is negatively connected to GW $\Delta \mathrm{D}$, as firms showing low returns on their assets are more likely to have impaired assets. High profitability, on the other hand, lowers the threshold to financing and growth through acquisitions. We had no clear expectation of how solvency (measured by EQUITY\%) would be connected to GW change. It can go both ways, a stronger balance sheet provides a good base for making acquisitions, but also leaves more room for write-downs. Firms with lower equity may be tempted to manage earnings upwards (i.e. try steer clear of write-downs) due to debt covenants (DeFond \& Jiambalvo, 1994) and being able to distribute dividends. The results from 1-year regressions show some indication $(\mathrm{p}<0.1)$ that a stronger balance sheet makes GW write-down more likely. A higher book-to-market ratio (B/M) is, as expected, positively connected to GW decreases based on our 2-year regressions. This is in line with the market having already priced in the required write-down before it occurs, and is evidenced also in previous studies (Francis et al., 1996).

Regarding our variables of interest, the variable describing the number of women on the board of directors (FBOD) shows a significant and positive connection to the GW $\Delta \mathrm{D}$ variable. Thus, the higher the number of women on the board of directors, the greater the likelihood of GW write-downs, and the less enthusiasm the firm displays for making acquisitions. In the regressions using the relative number of women to the total number of board members, the variable of interest (F\%BOD) has the expected sign, but it is only marginally statistically significant $(\mathrm{p}<0.1)$ on the regressions using data for the GW change year (year 0). Combining these findings, the presence of women on the board of directors appears to be associated with the change in $\mathrm{GW}$, and this association increases in strength especially with the number of women on the board (FBOD), and less so with the relative number of women on the board (F\%BOD). This is in line with previous studies, suggesting that there needs to be more than one woman on the board to achieve critical mass and influence the decisions made (e.g., Joecks et al., 2013; Torchia et al., 2011).

We also test how a female CEO (FCEOD) affects our GW change variable. We found some $(\mathrm{p}<0.1)$ indication that having a female CEO increases the likelihood that the GW change is negative. Thus, with a female CEO, a write-down is more probable than an acquisition, but this result should be treated with caution because we have only 15 female CEOs in the 1-year regressions and 27 in the 2-year regressions. In sum, the evidence indicates that our hypothesis, large GW increases are associated with less GDBs than large GW decreases, is supported. Furthermore, highly significant coefficients for WeakCGD variable received always opposite sign than gender variables supporting the view that board gender diversity reflects also good corporate governance.

\subsection{Robustness tests}

We use z-scores of our variables to check for possible outliers. In the previous research, z-scores above 3 are generally considered to be outliers (Kannan et al., 2015). Some outliers are found among our control variables (SALES, ROA, EQUITY\%, and B/M). The greatest number of outliers are found for the variable 
EQUITY\% in the 2-year data, where it is negative in 4 cases. Thus, we removed all observations with z-scores above 3 and ran our regressions again. The original results were not influenced by the elimination (not reported).

In our analysis, the GW change was a dummy variable regressed over the explanatory variables, in line with previous research (Giner \& Pardo, 2015). We test our regressions with a continuous dependent variable on the GW change. The results of our OLS regressions are weak, and we were able to obtain statistically significant results only after leaving out very high GW increases and decreases (not reported). Also Giner and Pardo (2015) reported clearly weaker statistical significance levels for explanatory variables in their OLS regression, compared to their probit model, when testing for GW impairments. When we removed GW increases and decreases of magnitudes exceeding total assets at the point of executing an acquisition, we obtained marginally significant results for our variables of greatest interest. For regressions on years -1 and 0 , FBOD and F\%BOD produce negative coefficients $(-0.012$ and -0.122$)$ and marginal statistical significance (p-values 0.097 and 0.060 ). The negative coefficients mean that observations with larger $\mathrm{GW}$ increases are likely to involve lower female participation, whereas large negative $\mathrm{GW}$ changes are associated with more women on the board, that is, the results are in line with our main analysis. FCEOD does not receive any statistical significance. Of the control variables, ROA (positive signs) produces the most consistent and statistically significant (p-values $<0.01$ ) results in our OLS regressions. Thus, as expected, high ROA is associated with GW increases and low ROA with GW decreases.

Although we control for differences between the two samples (GW increase and GW decrease), the results may be affected by an omitted variable in the regressions. The results are distorted, if this potential omitted variable is connected to the likelihood of a firm engaging in acquisitions or GW write-downs, and associated with female participation on the board of directors. We examine this issue by including also the year after the large GW change $(y e a r+1)$ in our dataset. After the large GW change year (year 0), the difference in the degree of female participation on the board of directors in the two samples decreases. In year +1 , the GW decrease sample has on average only a $10 \%$ higher relative number of women (F\%BOD) on the board of directors (value 0.303) compared with the increase sample (0.276), down from a difference of $14 \%$ in year 0 and $22 \%$ in year -1 . Examining the average number of women on the board of directors in year 1, the average in the GW decrease sample is 2.448 compared with 2.072 in the GW increase sample, a difference of $18 \%$. Thus, the difference in the average number of women on the board in the two samples remains quite high, but is nevertheless clearly lower compared with the difference of year 0 of $28 \%$ or year -1 of $42 \%$. The fact that female board membership in the two samples converges in the year after the large GW change, suggests that female participation is not overwhelmingly determined by firm characteristics.

In the same manner, it is expected that when we use data from year +1 in our regressions, we should evidence a much lower explanatory power when compared to the GW change in year 0 , which is indeed the case. Specifically, the coefficient of the number of women on the board of directors decreases clearly (from 0.366 to 0.216 ), and its statistical significance decreases (from $\mathrm{p}=0.003$ to $\mathrm{p}=0.074$ ). The variable $\mathrm{F} \% \mathrm{BOD}$ loses its statistical significance altogether. For both regressions, 
the Nagelkerke $\mathrm{R}^{2}$ drops (from 0.252 to 0.155 , and 0.230 to 0.148 , respectively). Again, the fact that the board structure has the highest explanatory power by far in our regressions at the time when the decision leading to the GW change was on the board's agenda suggests that the board structure matters in the GW decision. To summarize, our robustness analyses do not alter our original results and conclusions drawn. However, we do gain some more finesses regarding the phenomenon studied.

\section{Conclusions}

This paper focused on the impact of gender on firm decision-making. Specifically, we concentrate on acquisitions, where the board of directors plays a significant role in strategic decision-making and in orchestrating $\mathrm{GW}$ valuation and impairment testing. GW valuation is a challenge for both standard-setters and practitioners. We assume that decisions regarding $\mathrm{GW}$ valuation and its changes have great potential to reflect board gender diversity. Corporate acquisitions are high stakes transactions and therefore tell of the board's willingness to take on risk. The decision to write-down GW includes a high level of discretion and reveal information on the reporting practices of the firm. We presumed that boards with high ethics and inclinations towards accounting conservatism have a lower threshold to write-down GW.

Our data are drawn from the Nordic countries, which resemble each other, for example, in terms of high future-orientation, egalitarianism, institutional collectivism, and uncertainty avoidance (Karaibrahimoglu \& Cangarli, 2016). In line with our hypothesis, we find that firms making big GW-increasing acquisitions are likely to have fewer women on their board compared to firms making GW write-downs. These results are based on regressions on 294 observations from Nordic firms with high GW changes in the years 2009-2018. Our primary results bear several robustness tests. Nordic observations are useful in investigating how gender influences firms' decision-making, as the Nordic countries are among the most gender-equal in the world, and female representation on firms' board of directors is comparatively high. Our findings, that the presence of women on the board seems to be negatively connected to $\mathrm{GW}$, complement previous research on rising gender diversification on boards of directors. Our results are in line with a previous finding which show that women are not as eager as men to engage in corporate acquisitions (Levi et al., 2014).

Although there is a lot of research investigating how women influence corporate outcomes there is a lack of consensus in this research. Endogeneity issues surely influence the results in many papers (and maybe ours as well despite our controls). The results of Sila et al. (2016) show that discrimination against women in appointment procedures is one important underlying factor driving previous results. In societies with high discrimination, the women making it to the top need to be very exceptional individuals. Recently, for example, Bouteska and Mili (2021) suggested that in Southeast Asia where discrimination against women is high, a higher percentage of women executives leads to less risk aversiveness and better profitability of banks. As our findings are based on a sample 
from the gender-equal Nordic countries, we do not think discrimination issues are severely affecting our results.

While there is evidence that females reduce firms' acquisitions and the associated GW, the question of whether female influence also helps firms make better performing acquisitions remains unanswered. This issue we leave for future research. In addition, board decision-making dynamics as such, and including gender impact, would be a highly important and interesting theme for future research. Also, further insights on gender and board decision-making would be gained by focusing on the significance of gender diversity regarding the composition of various committees supporting the board of directors. This would be one way to shed further light in order to understand to what extend females at board are a token of a high quality corporate governance.

Acknowledgements We acknowledge comments received from participants of the 25th Nordic Academy of Management Conference (NFF 2019), University of Vaasa, Vaasa, Finland. We acknowledge also an anonymous reviewer for comments resulting in a more comprehensive literature review and more rigorous arguments. We thank Okko Takkinen and Valtteri Toivanen for their skillful research assistance with the data and editing the text layout.

Author contributions Not applicable.

Funding Open Access funding provided by University of Turku (UTU) including Turku University Central Hospital. No specific funding support.

Data availability Data available from the public sources detailed in the text. Some of the data is subject to third party restrictions. Data applied in this article is deposited, secured and backed up at the servers hosted by the University of Turku and Åbo Akademi University.

Code availability Not applicable.

\section{Declarations}

Conflict of interest The authors declare that they have no conflict of interest.

Open Access This article is licensed under a Creative Commons Attribution 4.0 International License, which permits use, sharing, adaptation, distribution and reproduction in any medium or format, as long as you give appropriate credit to the original author(s) and the source, provide a link to the Creative Commons licence, and indicate if changes were made. The images or other third party material in this article are included in the article's Creative Commons licence, unless indicated otherwise in a credit line to the material. If material is not included in the article's Creative Commons licence and your intended use is not permitted by statutory regulation or exceeds the permitted use, you will need to obtain permission directly from the copyright holder. To view a copy of this licence, visit http://creativecommons.org/licen ses/by/4.0/.

\section{References}

AbuGhazaleh, N., Al-Hares, O., \& Roberts, C. (2011). Accounting discretion in goodwill impairments: UK evidence. Journal of International Financial Management and Accounting, 22(3), 165-204.

Adams, R., \& Ragunathan, V. (2015). Lehman sisters. Unpublished Working Paper, University of Oxford, University of Queensland 
Adams, R. B., \& Ferreira, D. (2009). Women in the boardroom and their impact on governance and performance. Journal of Financial Economics, 94(2), 291-309.

Adams, R., \& Funk, P. (2012). Beyond the glass ceiling: Does gender matter? Management Science, 58(2), 219-235.

Adhikari, B. K., Agrawal, A., \& Malm, J. (2019). Do women managers keep firms out of trouble? Evidence from corporate litigation and policies. Journal of Accounting and Economics, 67(1), 202-225.

Ahern, K. R., \& Dittmar, A. K. (2012). The changing of the boards: The impact of firm valuation of mandated female board representation. Quarterly Journal of Economics, 127(1), 137-197.

Bajtelsmit, V. L., \& Bernasek, A. (1996). Why do women invest differently than men? Financial Counseling and Planning, 7, 1-10.

Barber, B. M., \& Odean, T. (2001). Boys will be boys: Gender overconfidence, and common stock investment. Quarterly Journal of Economics, 116(1), 261-292.

Bear, S., Rahman, N., \& Post, C. (2010). The impact of board diversity and gender composition on corporate social responsibility and firm reputation. Journal of Business Ethics, 97(2), 207-221.

Ben-Amar, W., Chang, M., \& McIlkenny, P. (2017). Board gender diversity and corporate response to sustainability initiatives: Evidence from the carbon disclosure project. Journal of Business Ethics, 142(2), 369-383.

Betz, M., O’Connel, L., \& Sheppard, J. M. (1989). Gender differences for proclivity for unethical behavior. Journal of Business Ethics, 8(5), 321-324.

Bhagat, C., \& Huyett, B. (2013). Modernizing the board's role in M\&A. McKinsey Quarterly., 45, 1-6.

Bouteska, A., \& Mili, M. (2021). Women's leadership impact on risks and financial performance in banking: evidence from the Southeast Asian Countries. Journal of Management and Governance, Published online: 02 August 2021, 1-32.

Brieger, S., Francoeur, C., Welzel, C., \& Ben-Amar, W. (2019). Empowering women: The role of emancipative forces in board gender diversity. Journal of Business Ethics, 155(2), 495-511.

Bruna, M., Dang, R., Scotto, M.-J., \& Ammari, A. (2019). Does board gender diversity affect firm risktaking? Evidence from the French stock market. Journal of Management and Governance, 23(4), 915-938.

Bugeja, M., Matolcsy, Z., \& Spiropoulos, H. (2012). Is there a gender gap in CEO compensation? Journal of Corporate Finance, 18(4), 849-859.

Campbell, K., \& Mínguez Vera, A. (2008). Gender diversity in the boardroom and firm financial performance. Journal of Business Ethics, 83(3), 435-451.

Campbell, K., \& Mínguez Vera, A. (2010). Female board appointments and firm valuation: Short and long-term effects. Journal of Management and Governance, 14(1), 37-59.

Carter, D. A., D’Souza, F., Simkins, B. J., \& Simpson, W. G. (2010). The gender and ethnic diversity of US boards and board committees and firm financial performance. Corporate Governance: An International Review, 18(5), 396-414.

Chalmers, K., Godfrey, J., \& Webster, J. (2011). Does a goodwill impairment regime better reflect the underlying economic attributes of goodwill? Accounting \& Finance, 51(3), 634-660.

Chen, L., Gramlich, J., \& Houser, K. A. (2019). The effects on board gender diversity on a firm's risk strategies. Accounting and Finance, 59(2), 991-1031.

Chen, S., Ni, X., \& Tong, J. Y. (2016). Gender diversity in boardroom and risk management: A case of R\&D investment. Journal of Business Ethics, 136(3), 599-621.

Croson, R., \& Gneezy, U. (2009). Gender differences in preferences. Journal of Economic Literature, 47(2), 448-474.

Dang, C., Li, Z., \& Yang, C. (2018). Measuring firm size in empirical corporate finance. Journal of Banking and Finance, 86, 159-176.

Davydov, D., Florestedt, O., Peltomäki, J., \& Schön, M. (2017). Portfolio performance across genders and generations: The role of financial innovation. International Review of Financial Analysis, 50, 44-51.

Deaves, R., Lüders, E., \& Luo, G. Y. (2009). An experimental test of the impact of overconfidence and gender on trading activity. Review of Finance, 13(3), 555-575.

Deaves, R., Lüders, E., \& Schröder, M. (2010). The dynamics of overconfidence: Evidence from stock market forecasters. Journal of Economic Behavior \& Organization, 75(3), 402-412.

DeFond, M., \& Jiambalvo, J. (1994). Debt covenant violation and manipulation of accruals. Journal of Accounting and Economics, 17(1-2), 145-176.

Eagly, A., \& Johnson, B. (1990). Gender and leadership style: A meta-analysis. Psychological Bulletin, $108(2), 233-256$. 
Emelianova, O., \& Milhomem, C. (2019). Women on boards 2019 progress report, MSCI GSI Research 1lc (December), 1-30

Erhardt, N. L., Werbel, J. D., \& Shrader, C. B. (2003). Board of director diversity and firm financial performance. Corporate Governance: An International Review, 11(2), 102-111.

Faccio, M., Marchica, M.-T., \& Mura, R. (2016). CEO gender, corporate risk-taking, and the efficiency of capital allocation. Journal of Corporate Finance, 39, 193-209.

Francis, B., Hasan, I., Wu, Q., \& Yan, M. (2014). Are female CFOs less tax aggressive? Evidence from tax aggressiveness. Journal of the American Taxation Association, 36(2), 171-202.

Francis, J., Hanna, D., \& Vincent, L. (1996). Causes and effects of discretionary asset write-offs. Journal of Accounting Research, 34, 117-134.

García Lara, J.-M., Osma, B., \& Scapin, A. (2017). The monitoring role of female directors over accounting quality. Journal of Corporate Finance, 45, 651-668.

García-Sánches, I.-M., Martinéz-Ferrero, J., \& García-Meca, E. (2017). Gender diversity, financial expertise and its effect on accounting quality. Management Decision, 55, 347-382.

Giner, B., \& Pardo, F. (2015). How ethical are managers' goodwill impairment decisions in Spanishlisted firms? Journal of Business Ethics, 132(1), 21-40.

Glaum, M., Schmidt, P., Street, D. L., \& Vogel, S. (2013). Compliance with IFRS 3- and IAS 36-required disclosures across 17 European countries: Company- and country-level determinants. Accounting and Business Research, 43(3), 163-204.

Gneezy, U., Leonard, K. L., \& List, J. (2009). Gender differences in competition. Evidence from a matrilineal and a patriarchal society. Econometrica, 77(5), 1637-1664.

Godfrey, J., \& Koh, P.-S. (2009). Goodwill impairment as a reflection of investment opportunities. Accounting \& Finance, 49(1), 117-140.

Gregoric, A., Oxelheim, L., Randøy, T., \& Thomsen, S. (2017). Resistance to change in the corporate elite: Female directors' appointments onto Nordic boards. Journal of Business Ethics, 141(2), 267-287.

Gul, F. A., Srinidhi, B., \& Ng, A. C. (2011). Does board gender diversity improve the informativeness of stock prices. Journal of Accounting and Economics, 51(3), 314-338.

Hardies, K., Breesch, D., \& Branson, J. (2016). Do (fe)male auditors impair audit quality? Evidence from going-concern opinions. European Accounting Review, 25(1), 7-34.

Haslam, S. A., Ryan, M. K., Kulich, C., Trojanowski, G., \& Atkins, C. (2010). Investing with prejudice: The relationship between women's presence on company boards and objective and subjective measures of company performance. British Journal of Management, 21(2), 484-497.

Hassine, N., \& Jilani, F. (2017). Earnings management behaviour with respect to goodwill impairment losses under IAS 36: The French case. International Journal of Academic Research in Accounting, Finance and Management Sciences, 7(2), 177-196.

Hodigere, R., \& Bilimoria, D. (2015). Human capital and professional network effects on women's odds of corporate board directorships. Gender in Management: An International Journal, 30(7), 523-550.

Huang, J., \& Kisgen, D. (2013). Gender and corporate finance: Are male executives overconfident relative to female executives? Journal of Financial Economics, 108(3), 822-839.

Hutchinson, M., Mack, J., \& Plastow, K. (2015). Who selects the 'right' directors? An examination of the association between board selection, gender diversity, and outcomes. Accounting \& Finance, 55(4), 1071-1103.

Ingersoll, A., Glass, C., Cook, A., \& Olsen, K. (2019). Power, status and expectations: How narcissism manifests among women CEOs. Journal of Business Ethics, 158(4), 893-907.

Isidro, H., \& Sobral, M. (2015). The effects of women on corporate boards on firm value, financial performance, and ethical and social compliance. Journal of Business Ethics, 132(1), 1-19.

Jackson, A. (2018). Discretionary accruals: Earnings management...or not? Abacus, 54(2), 136-153.

Joecks, J., Pull, K., \& Vetter, K. (2013). Gender diversity in the boardroom and firm performance: What exactly constitutes a “critical mass?". Journal of Business Ethics, 118(1), 61-72.

Jordan, C., \& Clark, S. (2004). Big bath earnings management: The case of goodwill impairment under SFAS No. 142. Journal of Applied Business Research, 20(2), 63-70.

Kannan, S., Manoj, K., \& Arumugam, S. (2015). Labeling methods for identifying outliers. International Journal of Statistics and Systems, 10(2), 231-238.

Karaibrahimoglu, Y., \& Cangarli, B. (2016). Do auditing and reporting standards affect firms' ethical behaviours? The moderating role of national culture. Journal of Business Ethics, 139(1), 55-75. 
Kilic, M., \& Kuzey, C. (2016). The effect of board gender diversity on firm performance: Evidence from Turkey. Gender in Management: An International Journal, 31(7), 434-455.

Knauer, T., \& Wöhrmann, A. (2016). Market reaction to goodwill impairments. European Accounting Review, 25(3), 421-449.

Lanis, R., Richardson, G., \& Taylor, G. (2017). Board of director gender and corporate tax aggressiveness: An empirical analysis. Journal of Business Ethics, 144(3), 577-596.

Larcker, D., \& Tayan, B. (2016). Corporate governance matters-a closer look at organizational choices and their consequences (2nd ed.). Pearson Education Inc.

Lee, P. M., \& James, E. H. (2007). 'She'-E-OS: gender effects and investor reactions to the announcement of top executive appointments. Strategic Management Journal, 28(3), 227-241.

Lev, B. (2019). Ending the accounting-for-intangibles status quo. European Accounting Review, 28(4), 713-736.

Levi, M., Li, K., \& Zhang, F. (2014). Director gender and mergers and acquisitions. Journal of Corporate Finance., 28, 185-200.

Li, Z., Shroff, P., Venkatararam, R., \& Zhang, I. (2010). Goodwill impairment loss: Causes and consequences. Review of Accounting Studies, 16, 745-778.

Luckerath-Rovers, M. (2013). Women on boards and firm performance. Journal of Management and Governance, 17(2), 491-509.

Mateos de Cabo, R., Gimeno, R., \& Escot, L. (2011). Disentangling discrimination in Spanish boards of directors. Corporate Governance: An International Review, 19(1), 77-95.

McNichols, M. (2000). Research design issues in earnings management studies. Journal of Accounting and Public Policy, 19(4-5), 313-345.

Moreno-Gómez, J., Lafuente, E., \& Vaillant, Y. (2018). Gender diversity in the board, women's leadership and business performance. Gender in Management: An International Journal, 33(2), 104-122.

Nielsen, S., \& Huse, M. (2010). The contribution of women on boards of directors: Going beyond the surface. Corporate Governance: An International Review, 18(2), 136-148.

Palvia, A., Vähämaa, E., \& Vähämaa, S. (2015). Are female CEOs and chairwomen more conservative and risk averse? Evidence from the banking industry during the financial crisis. Journal of Business Ethics, 131(3), 577-594.

Perrault, E. (2015). Why does board gender diversity matter and how do we get there? The role of shareholder activism in deinstitutionalizing old boys' networks. Journal of Business Ethics, 128(1), 149-165.

Post, C., \& Byron, K. (2015). Women on boards and firm financial performance: A meta-analysis. Academy of Management Journal, 58(5), 1546-1571.

Redor, E. (2016). Board attributes and shareholder wealth in mergers and acquisitions: A survey of the literature. Journal of Management and Governance, 20(4), 789-821.

Reese, B., \& McDougal, M. (2018). Gender, status, and tax offenses. Deviant Behavior, 39(12), 1647-1657.

Reguera-Alvarado, N., de Fuentes, P., \& Laffarga, J. (2017). Does board gender diversity influence financial performance? Evidence from Spain. Journal of Business Ethics, 141(2), 337-350.

Rose, C. (2007). Does female board representation influence firm performance? The Danish evidence. Corporate Governance: An International Review, 15(2), 404-413.

Rossi, F., Cebula, R., \& Barth, J. (2018). Female presentation in the boardroom and firm debt: Empirical evidence from Italy. Journal of Economics and Finance, 42(2), 315-338.

Siekkinen, J. (2017). Board characteristics and the value relevance of fair values. Journal of Management and Governance, 21(2), 435-471.

Sila, V., Gonzalez, A., \& Hagendorff, J. (2016). Women on board: Does boardroom gender diversity affect firm risk? Journal of Corporate Finance, 36, 26-53.

Smieliauskas, W., Bewley, K., Gronewold, U., \& Menzefricke, U. (2018). Misleading forecasts in accounting estimates: A form of ethical blindness in accounting standards? Journal of Business Ethics, 152(2), 437-457.

Srinidhi, B., Gul, F. A., \& Tsui, J. (2011). Female directors and earnings quality. Contemporary Accounting Research, 28(5), 1610-1644.

Srivastava, R. K. (2018). Merger, acquisition—right move or emotional move for growth—case study of sun pharmaceutical. International Journal of Pharmaceutical and Healthcare Marketing, 12(3), 270-287.

Stolowy, H., Lebas, M. J., \& Ding, Y. (2013). Financial accounting and reporting: A global perspective (4th ed.). Cengage. 
Sun, J., Liu, G., \& Lan, G. (2011). Does female directorship on independent audit committees constrain earnings management? Journal of Business Ethics, 99(3), 369-382.

Sundén, A. E., \& Surette, B. J. (1998). Gender differences in the allocation of assets in retirement savings plans. The American Economic Review, 88(2), 207-211.

Terjesen, S., Couto, E., \& Franciso, P. (2016). Does the presence of independent and female directors impact firm performance? A multi-country study of board diversity. Journal of Management and Governance, 20(3), 447-483.

Terjesen, S., Sealy, R., \& Singh, V. (2009). Women directors on corporate boards: A review and research agenda. Corporate Governance: An International Review, 17(3), 320-337.

Thiruvadi, S., \& Huang, H.-W. (2011). Audit committee gender differences and earnings management. Gender in Management: An International Journal, 26(7), 483-498.

Torchia, M., Calabrò, A., \& Huse, M. (2011). Women directors on corporate boards: From Tokenism to critical mass. Journal of Business Ethics, 102(2), 299-317.

United Nations. (2020). The world's women 2020: Trends and statistics. UN Department of Economic and Social Affairs.

Vähämaa, E. (2017). Female executives and corporate governance. Managerial Finance, 43(10), 1056-1072.

van Staveren, I. (2014). The Lehman sisters hypothesis. Cambridge Journal of Economics, 38(5), 995-1014.

Verriest, A., \& Gaeremynck, A. (2009). What determines goodwill impairment? Review of Business and Economics, 54(2), 106-128.

Wahid, A. (2019). The effects and the mechanisms of board gender diversity: Evidence from financial manipulation. Journal of Business Ethics, 159(3), 705-725.

Wilson, N., \& Altanlar, A. (2011). Director characteristics, gender balance and insolvency risk: An empirical study. Working paper, University of Leeds -Credit Management Research Centre, 1-54.

Zalata, A., Ntim, C., Aboud, A., \& Gyapong, E. (2019). Female CEOs and core earnings quality: New evidence on the ethics versus risk-aversion puzzle. Journal of Business Ethics, 160(2), 515-534.

Zalata, A., Ntim, C., Alsohagy, M., \& Malagila, J. (2021). Gender diversity and earnings management: The case of female directors with financial background. Review of Quantitative Finance and Accounting, Published online: 24 June 2021, 1-36.

Zhang, J. Q., Zhu, H., \& Ding, H. B. (2013). Board composition and corporate social responsibility: An empirical investigation in the post Sarbanes-Oxley Era. Journal of Business Ethics, 114(3), 381-392.

Publisher's Note Springer Nature remains neutral with regard to jurisdictional claims in published maps and institutional affiliations. 